\title{
The Impact of Civil Status on Women's Wages in Brazil
}

\author{
Regina Madalozzo \\ Professora - Insper - Instituto de Ensino e Pesquisa \\ Endereço para contato: Rua Quatá, 300, $4^{\circ}$ andar - CEP 04546-042 - São Paulo - SP \\ E-mail: reginam@insper.edu.br

\section{Carolina Flores Gomes} \\ Graduada em Economia e Administração - Insper - Instituto de Ensino e Pesquisa \\ Endereço para contato: Rua Quatá, 300, $4^{\circ}$ andar - CEP 04546-042 - São Paulo - SP \\ E-mail:carolinafg@al.insper.edu.br
}

Recebido em 20 de julho de 2011. Aceito em 09 de maio de 2012.

\begin{abstract}
Consensual union, also known as cohabitation, has become more frequent in recent decades in Brazil and many other countries. In this context, some studies have analyzed the impact of marriage on women's wages. This article analyzes the effects of marital status on Brazilian women's wages by specifically investigating the individual characteristics of these effects using data from the 2000 Brazilian Census Database. This study concludes that wages differ by up to 15 per cent between married and single women and up to 3 per cent between married and cohabiting women.
\end{abstract}

\section{Keywords}

marriage, cohabitation, wage differential, sample selection

\section{JEL Classification}

$\mathrm{J} 12, \mathrm{J16}, \mathrm{J} 71$

\section{Resumo}

A união consensual, também conhecida como coabitação, é um fenômeno que tem sido cada vez mais frequente nas últimas décadas, não somente no Brasil, mas também nos mais diversos países. Ao mesmo tempo, surgiram estudos sobre o impacto do casamento no salário das mulheres. O presente artigo analisa o efeito do estado civil nos salários das mulheres que residem no Brasil. Para tanto, esse estudo utiliza as características individuais para a análise dos efeitos colhidas através do Censo Brasileiro realizado em 2000. As conclusões mostram que existe diferença salarial de até $15 \%$ entre mulheres casadas e solteiras e essa diferença é de até $3 \%$ entre mulheres casadas e coabitantes.

\section{Palavras-Chave}

casamento, coabitação, diferencial de salários, seleção amostral

- Authors would like to thank Adriana Bruscato, Naércio Aquino de Menezes Filho and four anonymous referees for helpful comments. 


\section{Introduction}

In recent decades, several transformations have occurred in family formation patterns, such as the dissolution of unions and familial arrangements, in many countries, including Brazil. Following the growth of women's labor market participation after the 1960s, these changes in the family unit have become more common. More specifically, decreases in fertility, increases in the propensity of informal unions, increases in marital age, and increases in the number of divorces are strong indications of these transformations (Becker, 1992; Falcão and Soares, 2008).

In Latin America, consensual unions have existed since the colonial period, and a considerable number of these unions have never been legalized, thus resulting in informal unions that are independent of marriage (Martin, 2002). In 1988, the Federal Constitution of Brazil recognized informal unions as stable unions, giving cohabitants the same legal rights that are granted to officially married couples. Until then, consensual unions were typically associated with lower socioeconomic classes and were not recognized by civil authorities. Since this new legislation, however, members from other socioeconomic classes have adopted informal unions as an alternative to civil marriage, increasing the number of consensual unions.

With the increasing popularity of informal unions and the lack of studies that are directed specifically at Brazilian women, this study utilizes data from the 2000 Demographic Census ${ }^{1}$ to analyze possible characteristics that explain wage differences among women based on their civil status. The objective of this study is to explain the effects of civil status on Brazilian women's salaries by evaluating individual characteristics and analyzing specific social and economic variables to identify possible differences between the earnings and activities of married, single and cohabitating women.

Previous studies on male wages show that married men and cohabiting men earn higher salaries than do single men (Zavodny, 2008). Hersch and Stratton (2000) justify this increase in the remuneration

1 Instituto Brasileiro de Geografia e Estatística (Brazilian Institute of Geography and Statistics, IBGE). We used the 2000 Demographic Census, the most recent microdata available at the time of this research. Results from 2010 Census were not available by the time of this research, which would substantially contribute to analyze differences on labor markets that occurred during the last decade. Future research goals include making a comparative analysis. 
by the household specialization that usually occurs after a couple is united: the man goes to the labor market and the woman, even if engaged in the labor market, is responsible for household care and home production (Becker, 1973). This division would increase male productivity for market labor and, consequently, generate higher wages for married men compared with single men. However, the same effect is not well understood for women. In other words, would married women earn more than single women because, like men, they have become more productive, increasing their remuneration in the labor market, or would they earn less than single women because they must accommodate two different demands (labor and home production for a couple)? The results for the United States show that single women receive higher wages than married and cohabiting women (Madalozzo, 2008), and the explanation for this difference is related to the fact that single women have more time to invest in their careers when compared with married or cohabiting women, who have double demands placed on their time: home and work.

This study contributes to the literature by evaluating the impact of marital status on income differentials among Brazilian women. Our analysis uses the ordinary least squares (OLS) method to control for two selection problems: labor market participation and civil status choice. We also show that the Brazilian environment for women is completely different from that in the United States. Salaries differ by up to 15 per cent between married and single women and up to 3 per cent between married and cohabitating women, with both differences favoring married women. Our conclusions are founded upon the different signals captured by distinct labor market settings.

This paper is organized as follows. Section 2 reviews the existing literature, and section 3 briefly analyzes the base data in this stu$\mathrm{dy}$ and provides a descriptive analysis of the data to compare the socioeconomic characteristics of each group. Section 4 discusses the analytical methodology of the study, and section 5 presents the estimated regressions and result comparisons for each sub-sample based on Oaxaca-Kuhn wage decomposition. Section 6 presents the conclusions. 


\section{Previous Literature}

This section is divided into two parts. The first presents a brief description of the social and economic changes that have encouraged the observed increase in the number of informal unions in Brazil, while the second presents a brief summary of the existing literature and summarizes the principal variables analyzed in prior studies, especially those variables that have been shown to influence women's marital status choices, women's participation in the labor market, and salary differences.

\subsection{Historical Context}

For many years, marriage was viewed as a contract that established morals and rules of conduct and assigned marriage a specific role within a patriarchal society, that is, to perpetuate dominant and subordinate roles for men and women, respectively. The marriage contract not only negotiates a woman's individual sexual authority but also weds political and economic rights and a woman's rights to manage her own existence. These facts show the paternalistic construction of the marriage contract, which guaranteed male superiority and the husband's power.

The main changes in social behavior in the context of marriage began during the first and second world wars, wherein women often had to assume men's roles. With the consolidation of the capitalist system in the nineteenth century, some laws began to uphold the rights of women. The entry of women into the labor market in the mid-1960s helped to further change sexist perceptions in society. However, even with these achievements, women continue to face exploitation and inequality at home, at work, and in the eyes of the law.

Since the 1960s in Brazil, the number of separations and divorces has increased. Since 1942, according to civil code, separation without dissolution of the union or divorce was permitted (Berquó, 1998). In the 1950s and 1960s, the number of consensual unions increased among the poorest classes. During this period, consensual unions became an alternative for people who lacked the resources or were not interested in assuming the rights and obligations demanded by formal unions (Medeiros and Osorio, 2000). Marriage creates a series of transaction costs that, in turn, generate barriers for some 
individuals (as the double shift explored in Ferber and Birnbaum, 1977; Becker, 1965). In December 1977, divorce was established by law 6515 in Brazil. ${ }^{2}$ This new law was created to reduce the number of informal unions by removing some of the impediments to formal union; however, instead, there was an increase in the number of informal unions.

It was not until in 1988 that Brazil's constitution formally recognized this type of relationship as a stable union. In the 1990s, women's participation in the labor market increased, adding participation in the labor force to the responsibilities of being solely responsible for the household, thereby creating a double workday for women. In 1995, according to Berquó (1998), the rate of consensual unions was 23.5 per cent, and close to a quarter of these unions constituted informal relations. According to the 2000 Instituto Brasileiro de Geografia e Estatística (Brazilian Institute of Geography and Statistics, IBGE) data, 28.6 per cent of the unions in Brazil among people who were older than 15 were informal.

In Brazil, the number of informal unions has significantly increased in recent years. The gross marriage rate declined between 1979 and 1994, with the greatest decline in 1983, which was the worst year of the 'crisis of the lost decade,' when household income decreased significantly. Today, consensual union is not associated with low income. Young people who principally live in urban centers see consensual union as a way to continue their life as a single person or as a type of 'experimental marriage' to test the feasibility of their life as a couple. According to Berquó (1998), this trial may become permanent, a break with traditional norms and values.

\footnotetext{
2 The divorce request in Brazil may be conducted by both members of the couple or by one member alone. Designation for the first type of request is "consensual" and, for the second, "litigious". These different possibilities may affect the premarital search of a partner, as described in Rasul (2006).
} 


\subsection{Previous Empirical Research}

According to empirical studies, consensual unions have become more frequent in recent decades in Brazil and in the United States (Madalozzo, 2008) and Europe (Kiernan, 2002). Legislation in some countries, including Brazil, ${ }^{3}$ gives cohabitants the same legal rights that are accorded married couples. Cohabitants that spend a given amount of time together are, under the law, officially considered to be in a stable union. As a consequence, some couples opt not to formalize their marriages because, as cohabitants, they are already considered married.

The empirical literature shows a premium associated with marriage when men are the object of the study, whereas similar studies on women are inconclusive (Korenman and Neumark, 1991). When studying the effect of choices regarding marital status on women's earnings, we must consider the factors that influence women's decisions to establish either a formal (marriage) or an informal (cohabitation) relationship. However, independent of the formal or informal status of marriage, when a man and a woman make the decision to live together, the optimal division of work and its effects on the individual wages deserve study.

As Becker (1965) posits, the most efficient division, in view of aggregate consumption, is to dedicate one person fully to the labor market - the person who receives the higher payment for his/ her labor supply - and the other person to household production. According to Becker (1985), even the additional effort women spend taking care of children and domestic tasks would be sufficient to reduce their hourly wage when compared with male wages. Chiappori (1988) explores the subject of labor supply by family members considering a collective approach that allows different sets of utility functions to be maximized. Within his framework, it was possible to model the couple's decision over individual labor supply and Pareto-efficient result.

Furthermore, decisions regarding continuing or breaking the marriage contract may be posed in a model (as in Lundberg and Pollak, 1993) with separate spheres of bargaining power where the marriage

3 Since the 1990s, any couple living together for more than a year has the same rights as an officially married couple (Código n. 9278, March 10, 1996). 
contract may not be broken (as posed in the models of threat point - see Manser and Brown, 1980). However, the equilibrium result may be a non-cooperative point where traditional gender roles, e.g., division of work, would be preserved. Rasul (2006) explores the subject of the marriage market over changes in the divorce laws from consensual to unilateral request. At the same time, Rasul's (2006) model predicts an initial increase in divorce rates that would stabilize over time with an increase in the benefits of better searching and the resultant creation of a selection effect that would result in a more efficient searching process and more stable marriages.

Another question about marriage for women, even today, is its association with maternity. In most cases, women are responsible for childrearing, even in the case of divorce. Some studies have considered the impact of children on women's wages (Moore and Wilson, 1982) and, consequently, the impact of marriage (Hill, 1979); however, according to Bumpass, Sweet and Cherlin (1991), among North Americans, over 10 per cent of cohabiting couples have children and almost 25 per cent bring children from other relationships into their unions. These figures provide evidence that motherhood is no longer exclusively linked to marriage.

With respect to the choice of conjugal status, earlier studies affirm that cohabitation is common in large urban centers. In other words, women who live in large metropolises have a greater tendency to cohabit. Since the period following military dictatorship in Brazil, societal transformation has intensified and young people who live in urban centers see consensual unions as a way to continue single life or construct an 'experimental marriage' (Berquó, 1998).

Madalozzo (2008) used Current Population Survey (CPS) data from 1995, 1997, and 1999 about American women between 20 and 64 years of age and analyzed the wage differences between married and cohabiting women. Using switching regression methods and the Oaxaca decomposition, this study shows the existence of a financial penalty for married women. The salaries of married and cohabiting women differ from 49 per cent to 53 per cent, clearly favoring cohabiting women. In other words, women are penalized for being married. 
The literature on wage differences among Brazilian women according to marital status is not well developed. Studies have been conducted on the declining number of formal unions (Miranda-Ribeiro, 1993), the impact of increasing numbers of consensual unions (Greene and Rao, 1992), and the reasons for the increased popularity of consensual unions (Berquó, 1998) in Brazil; however, no study has focused on the wage differences of women according to their civil status. The literature on this topic is currently restricted to international studies.

The next section presents a brief analysis of the data used in this study and a descriptive analysis of the data. This analysis was separately undertaken for each marital status; that is, the means, proportions, and variances of three different samples - married, single, and cohabiting - were analyzed to compare each group's socioeconomic characteristics.

\section{Descriptive Analysis}

An important detail in the data analysis is the scheme used to classify cohabitants, determining whether a woman more closely resembles a married or single woman. In certain aspects, such as work profile, hours worked, and labor market participation as a whole, cohabitants resemble single women. On the other hand, considering years of education, race, and number of children, these women appear married. Considering these disparities, it is reasonable to separate the sample into two sub-samples. Thus, the analysis will be conducted in two parts: comparisons between married and single women and comparisons between married and cohabitant women. We will use a group of married women as the basis of comparison for the single and cohabitant women. 
Table 1 - Descriptive Analysis of the Data

\begin{tabular}{|c|c|c|c|}
\hline & Single & Cohabitant & Married \\
\hline \multirow{2}{*}{ Age } & 29.46 & 34.33 & 41.48 \\
\hline & -10.48 & -10.76 & -11.8 \\
\hline \multirow{2}{*}{ Annual salary } & $5,184.02$ & $4,382.46$ & $5,689.35$ \\
\hline & $-9,464.83$ & $-12,656.78$ & $-14,704.05$ \\
\hline \multirow{3}{*}{ Annual salary (women who work and have income) } & $5,427.34$ & $4,718.13$ & $6,501.38$ \\
\hline & $-9,615.99$ & $-13,072.11$ & $-15,549.56$ \\
\hline & {$[536,014]$} & {$[522,701]$} & {$[1,221,837]$} \\
\hline \multirow{2}{*}{ Hours of work per week } & 40.74 & 40.61 & 38.48 \\
\hline & -13.59 & -15.85 & -15.43 \\
\hline \multirow{2}{*}{ Hourly wages } & 3 & 2.55 & 3.43 \\
\hline & -7.24 & -8.49 & -10 \\
\hline \multirow{3}{*}{ Hourly wages (women who work and have income) } & 3.15 & 2.74 & 3.92 \\
\hline & -7.38 & -8.78 & -10.6 \\
\hline & {$[536,014]$} & {$[522,701]$} & {$[1,221,837]$} \\
\hline \multirow{2}{*}{ Number of children } & 0.27 & 2.75 & 3.3 \\
\hline & -0.77 & -2.39 & -2.77 \\
\hline \multicolumn{4}{|l|}{ Region (\%) } \\
\hline North & 5.17 & 9.8 & 5.23 \\
\hline Northeast & 28.61 & 31.41 & 24.86 \\
\hline Central-west & 6.16 & 7.89 & 6.87 \\
\hline South & 13.05 & 13.13 & 18.3 \\
\hline Southeast & 47.01 & 37.77 & 44.75 \\
\hline \multicolumn{4}{|l|}{ Years of schooling (\%) } \\
\hline No schooling & 6.52 & 13.53 & 12.01 \\
\hline 1 to 4 years & 16.59 & 36.03 & 38.39 \\
\hline 5 to 8 years & 19.24 & 29.33 & 21.63 \\
\hline 9 to 11 years & 39.24 & 16.86 & 19.41 \\
\hline 12 to 15 years & 15.02 & 3.23 & 6.58 \\
\hline Over 15 years & 3.39 & 1.02 & 1.97 \\
\hline \multicolumn{4}{|l|}{ Status in the home $(\%)$} \\
\hline Head of Household & 18.86 & 26.46 & 18.21 \\
\hline Wife / Partner & - & 67.13 & 78.38 \\
\hline Other & 81.14 & 6.41 & 3.41 \\
\hline \multicolumn{4}{|l|}{ Ethnicity (\%) } \\
\hline White & 56.48 & 44.68 & 61.02 \\
\hline Black & 7.24 & 8.8 & 5.07 \\
\hline Asian & 0.68 & 0.22 & 0.52 \\
\hline Parda & 35.06 & 45.57 & 33.06 \\
\hline Indigenous & 0.26 & 0.72 & 0.33 \\
\hline Resident in an urban center $(\%)$ & 85.06 & 82.21 & 77.78 \\
\hline Number of observations & 964,968 & $1,310,228$ & $3,265,541$ \\
\hline
\end{tabular}

Source: IBGE, data tabulated by the author.

Notes: 1) Standard deviations from the mean (SD) are in parentheses.

2) Bracketed values represent the number of observations used to calculate the corresponding variable. 
This study uses data from the 2000 Brazilian Demographic Census. The Demographic Census is a national research project that was developed by the IBGE and executed over 10 years to collect information about the entire Brazilian population. We used the sample micro data made available by IBGE.

The sample in this study contains observations on women who were between 20 and 64 years of age and who belong to an economically active population. These women were divided into married (58.93 per cent), single (17.42 per cent), and cohabitation ( 23.65 per cent) groups. As a first step, we analyzed the social and economic characteristics of women living in Brazil based on marital status to identify the relevant features that distinguish the earnings of women who live in consensual unions, single women, and legally married women.

As shown in Table 1, with respect to income, we see that both the annual salary and the hourly wage of married women are higher than those of single women and those women in informal unions have the lowest pay. Considering only women who work and have income, cohabiting women earn an average annual salary that is nearly 38 per cent less than married women. Single women earn approximately 20 per cent less than formally married women. Single women and women in consensual unions work many more hours, further increasing the difference between the average hourly wages of these women when compared with those who are officially married. The wages of married women are less than the wages of single women and cohabitants by approximately 24 per cent and 43 per cent, respectively.

In Table 1, when we examine the ages of Brazilian women, we see that the mean age of single women is 11 years lower than that of married women; however, the mean age of women who are living in consensual unions is approximately 7 years lower than that of married women. In other words, the phenomenon of consensual union takes place largely among younger people; however, it is noteworthy that this phenomenon extends to older people in Latin America, which is in contrast to many developed countries, such as the United States and some European countries (Martin 2002).

Today, the view that official marriage is highly related to maternity persists. This view suggests that married women should have a greater number of children than cohabiting women. The data in Table 1 
show that married women have, on average, a greater number of children; however, this difference is not significant. Whereas married women have a mean of 3.3 children, cohabiting women have a mean of 2.75 children. Couples in consensual unions have children without formalizing their marriages, suggesting that consensual union now an alternative to legal marriage rather than a trial period. With respect to the average number of children, single women have, on average, fewer children.

If we analyze the educational levels of Brazilian women using the data in Table 1, women with the highest levels of education, mostly in the range of 9 to 11 years of study with a relatively elevated percentage in the range of 12 to 15 years of study, opt to remain single. Women in consensual unions were concentrated among women of lower education levels or among those who did not finish junior high school, with the majority having 5 to 8 years of schooling.

Observing the data on household status, a greater proportion of women in formal and informal unions are classified as wife (78.58 per cent) or partner (67.13 per cent). However, among cohabiting women, the proportion of those in the role of head of household ${ }^{4}$ is greater than that in married and single women, indicating that these women contribute substantially to the economic well-being of their families. $^{5}$

In an examination of the ethnicity of Brazilian women, consensual unions are chosen, in large part, by black and parda women. White women appear to prefer to remain single or forming formal unions. In Brazil, since the colonial period, informal relationships have been prevalent among black women. During this period, slaves who were involved with white men did not establish formal unions. The children of these unions often did not know for certain who their fathers were, and the idea of an informal union was part of the cultural heritage, as a break and a type of independence from traditional European customs. Until recently, racial discrimination has reduced the economic potential of black and mulatto women compared with that of white women.

\footnotetext{
4 Heads of household are women who are considered to be responsible for the household or who are considered so by other residents.

5 Nearly 27 per cent of cohabiting women are the heads of households; however, among married and single women, the proportion is near 18 per cent.
} 
Earlier studies (Berquó, 1998) show that the increase in the number of consensual unions is a phenomenon of large urban centers. When analyzing the urban center variable, we see a significant difference in the proportion of women in consensual unions between urban centers and rural areas. Living in an urban center may, therefore, increase the likelihood of women to opt for an informal union, which would impact earnings. As a result, we decided to include this variable in the model.

The next section describes this study's methodology, which was divided into three parts: our econometric methods, issues in the selection of women with respect to their labor market participation and choice of civil status, and potential corrections for these issues.

\section{Methodology}

This study uses OLS to estimate the coefficients of a multiple linear regression and analyze the differences in women's wages by civil status. OLS uses a mathematical optimization technique to find the best fit for a data set by minimizing the sum of the squares of the differences between the fitted model and the observed data, where

$$
\min _{\beta \in \Re^{p}} \sum_{i=1}^{n}\left(y_{i}-x_{i}^{\prime} \beta\right)^{2}
$$

To analyze the wage differences between women who are married, single, and those living in consensual unions, we use two separate sub-samples, one to compare married with single women, and another to compare married with cohabitant women. A regression was estimated using the natural logarithm of hourly wages as the dependent variable (in reais) as explained by the independent variables of experience, ${ }^{6}$ experience squared, number of children, ${ }^{7}$ level of education, ${ }^{8}$ race, ${ }^{9}$ the woman's geographic region of residence, ${ }^{10}$

6 Constructed variable: age - number of years of study - six.

7 Considering only children born alive.

8 These categories include uneducated, from 1 to 4 years of study, from 5 to 8 years of study, 9 to 11 of study, 12 to 15 years of study, and more than 15 years of study. Excluded category: uneducated.

9 These categories include black, parda, yellow, and indigenous. Excluded category: white.

10 These categories include southeast, south, central-west, north, and northeast. Excluded category: southeast. 
position in the family, ${ }^{11}$ and occupation. To refine the analysis, the sample was separated into two sub-groups - women who work full time (40 hours or more per week) and women who work part time (less than 40 hours per week). This division allows us to investigate the behavioral profiles of these women and the signals that they send to the market regarding their dedication (in time) to work.

\subsection{Selection Problems}

The first stage of this study estimated a multiple linear regression in which the analyzed responding variable was the natural logarithm of hourly wages (in reais); however, an analysis of the effects of multiple linear regressions may generate biased results. Previous studies point to a selection problem among women regarding their labor market participation. ${ }^{12}$ Women have different patterns of selection in the labor market given that their participation is largely discontinuous due to having children, which can lead women to leave the labor market. It is necessary to consider the possibility of differences in unobserved characteristics and abilities because these differences influence women's participation in the labor market and, consequently, their wage levels.

Women with different skill characteristics choose whether to enter the workforce. Although raising small children increases labor costs, the level of education and experience may have the opposite effect. To estimate the probability of labor market participation, we use the number of children who are younger than 6 years of age, indicators of education, indicators of race, experience, and experience squared. Previous studies show that black women have a greater participation in the labor market, primarily because their income is required for survival rather than just improved quality of life. To account for this phenomenon, race indicators were included. In addition to these intuitive variables, marital status indicators were also included. The expected sign for the marital status indicator is positive because the theory of domestic production affirms that the division of labor is most efficient when each family member devotes his or her time to the most productive work. Men usually receive greater compensation for their time in the labor market than in domestic production.

11 These categories include head of household and others. Excluded category: others.

12 For more information on selection problems, see Vella (1998) and Heckman (1979). 
The expectation is that married women spend more time in household activities and less time in the labor market. These phenomena will result in different probabilities for work based on marital status.

Another problem in this study is the selection of conjugal status. Given certain characteristics, women generally choose to live in consensual unions or marriage. The choice among different marital statuses may also reflect unobservable characteristics of the subsample. If these unobservable characteristics act as much on choice of conjugal status as on the wage level, disregarding these influences can bias the study results.

Addressing this problem is important because if we consider that women who are more capable choose to marry and those who are less capable choose consensual unions, ignoring this type of selection would incorrectly include a bias for ability in the estimated coefficient for conjugal status. Addressing this issue can correct the bias and provide the actual effects of marriage on salary. Earlier studies point to an increase in consensual unions as typical in urban centers (Chevan, 1996). Also, descriptive analysis shows that the mean age of cohabitants is less than the mean age of married women. To estimate the probability of a woman choosing an informal union, the indicators of age, living in an urban center, education, and race were used in this study.

\subsection{Correction of Selection Problems}

To correct the problems of selection in labor force participation and choice of marital status, bivariate probit regression ${ }^{13}$ was used in the model specified by Lee (1983). We used the inverse Mills ratio (IMR) as a regressor in the wage equation. The IMR is defined

as the following: $I M R=\frac{\varphi\left(Z^{\prime} \gamma / \sigma_{0}\right)}{\Phi\left(Z^{\prime} \gamma / \sigma_{0}\right)}$

\footnotetext{
${ }^{13}$ If the selection problem was unique, as usually it is when estimating a Mincerian equation for female wages, we could use a univariate probit regression, as explained in Heckman (1979). However, having two selection sources, it is more adequate to use a bivariate probit regression or to run two probit models, one for each selection problem. We used both methods, and the results did not differ significantly; therefore, we choose the more sophisticated solution, a bivariate probit correction that generates two IMRs, correcting both selection difficulties.
} 
where $Z^{\prime} \gamma$ represents the regressors of the probit equation and $\sigma_{0}$ is the standard deviation of the residuals of the original equation that contains the problem of selection bias. When we use this correction method by including the IMR in the equation, the individual marginal effect of each dependent variable and the indirect effect of the $\mathrm{IMR}^{14}$ coefficient should be considered. Note that instead of having an identified model, some authors suggest that the probit regression must include at least one variable that is not a regressor in the multiple linear model. The variables for the bivariate probit model that indicate a woman with a child under 6 years of age were used for the probit model of participation in the workforce, whereas residing in an urban center was used for the probit model of choosing civil status. In the multiple linear regression model, these variables were excluded.

Note that in the new regression of salary, the two IMRs are included in the regression such that the estimated coefficients can be interpreted using the correction to calculate the marginal effects. The obtained results were used to predict wage differences by marital status using the Oaxaca (1973)-Kuhn(1987) decomposition, as is common in the wage differential literature (see Allegretto and Arthur, 1999; Koreman and Neumark, 1991; Kun, 1987, among others).

To decompose the wage difference into two parts (explained and unexplained), the Oaxaca-Kuhn methodology requires the estimation of two Mincerian equations, one for:

$$
\ln \left(W_{i}\right)=\sum_{i} \beta_{i} X_{i}+u_{i}
$$

where $W_{i}$ is the hourly wage for worker $i, X_{i}$ is the vector of individual characteristics, $\beta$ is the regression coefficient and $u_{i}$ is the error. These estimations will result in two sets of estimated coefficients, one for each group.

The individual characteristics of the sample and the estimated coefficients can be used to obtain the discrimination factor, which is the difference in the observed average of women's wages between

${ }^{14}$ This subject is discussed extensively in Hoffman and Kassouf (2005), Saha, Capps and Byrne (1997), and Heckman (1979). 
one group (married) and another group (cohabitant or single), ${ }^{15}$ as shown below:

$$
\hat{D_{i}}=\sum_{j} \hat{\beta}_{j}^{\text {married }} X_{i j}^{\text {married }}-\sum_{j} \hat{\beta}_{j}^{\text {cohabiting/single }} X_{i j}^{\text {married }}
$$

In this study, we use the Oaxaca-Kuhn method to calculate the wage differences between married and cohabitant/single women.

To identify the contribution of each variable to the explained and unexplained gap, this study uses the Yun (2005) method, as used in the Scorzafave and Pazello (2007) paper. On the basis of the Oaxaca and Ramson (1999) study, Yun (2005) identified an indetermination problem and proposed a methodology to disentangle the identification problem. Based on the normalized regressions, he estimates "normalized" equations by imposing the restriction that the sum of the dummies' coefficients must be zero. ${ }^{16}$ The next section presents the estimated regressions and comparisons of the results for each analyzed sample based on the Oaxaca-Kuhn wage decomposition test.

\section{Results}

This section is divided into three parts. The first part presents the results of the bivariate probit model, which were estimated to correct the selection problems, and the estimated results of the IMR coefficients of each of the selection problems. The second part presents the results obtained by the ordinary least squares method for the two sub-samples, while the third part presents results from the wage differential findings.

\footnotetext{
${ }^{15}$ To be more specific, using the characteristics of married women on estimated coefficients for the Mincerian wage equation for the married sample yields the wage a married women is supposed to receive when she is married. Using the same characteristics of married women but the estimated coefficients for the Mincerian wage equation for cohabiting (or single) sample gives the wage a married woman would receive if, instead of being married, she was cohabiting (or single). Because the estimations consider all the sample characteristics and we use the same sample being evaluated in two situations, the difference of these predictions represents the difference of wage by marital status alone.

${ }^{16}$ This subject is extensively discussed in Scorzafave and Pazello (2007) and Yun (2005).
} 


\subsection{Bivariate Probit}

Utilizing the 2000 Demographic Census data that were collected by the IBGE, we performed analyses with respect to individual, social, and economic characteristics. In addition, we analyzed the wage differences between women in consensual unions and those who are legally married. Tables 2 and 3 present the results obtained by estimating the bivariate probit model for sub-samples of marriedcohabitant and married-single subjects, respectively.

As shown in Tables 2 and 3, when women in consensual unions or single women have a greater likelihood of being in the labor market. For cohabiting women, this relation can be explained by the fact that most women who are involved in informal relationships contribute to family income. These women have great influence within the family because childrearing and household responsibilities increase the need to be in the labor market. 
Table 2 - Bi-Probit of Married $\times$ Cohabitant Women

\begin{tabular}{|c|c|c|}
\hline Married $\times$ Cohabitant & Probit to be in the labor market & Probit to become cohabitant \\
\hline \multirow{2}{*}{ Constant } & -1.525 & 0.772 \\
\hline & -0.005 & -0.004 \\
\hline \multirow{2}{*}{ Indicator for cohabitant } & 0.967 & - \\
\hline & -0.007 & \\
\hline \multirow{2}{*}{ Resident in urban center } & - & 0.439 \\
\hline & & -0.002 \\
\hline \multirow{2}{*}{ Age } & - & -0.039 \\
\hline & & -0.00007 \\
\hline \multirow{2}{*}{ Experience } & 0.071 & - \\
\hline & -0.0003 & \\
\hline \multirow{2}{*}{ Experience squared } & -0.002 & - \\
\hline & $-5.02 E-06$ & \\
\hline \multirow{2}{*}{ Children $<6$ years of age } & -0.241 & - \\
\hline & -0.002 & \\
\hline \multirow{2}{*}{1 to 4 years of schooling } & 0.282 & -0.332 \\
\hline & -0.002 & -0.002 \\
\hline \multirow{2}{*}{5 to 8 years of schooling } & 0.476 & -0.391 \\
\hline & -0.003 & -0.003 \\
\hline \multirow{2}{*}{9 to 11 years of schooling } & 0.871 & -0.692 \\
\hline & -0.003 & -0.003 \\
\hline \multirow{2}{*}{12 to 15 years of schooling } & 1.345 & -0.843 \\
\hline & -0.004 & -0.004 \\
\hline \multirow{2}{*}{ Over 15 years of schooling } & 1.579 & -0.796 \\
\hline & -0.006 & -0.007 \\
\hline \multirow{2}{*}{ Black } & 0.035 & 0.48 \\
\hline & -0.003 & -0.003 \\
\hline \multirow{2}{*}{ Asian } & -0.09 & -0.148 \\
\hline & -0.01 & -0.013 \\
\hline \multirow{2}{*}{ Parda } & -0.022 & 0.25 \\
\hline & -0.002 & -0.002 \\
\hline \multirow{2}{*}{ Indigenous } & -0.186 & 0.626 \\
\hline & -0.01 & -0.01 \\
\hline \multirow{2}{*}{ North } & -0.262 & 0.468 \\
\hline & -0.003 & -0.003 \\
\hline \multirow{2}{*}{ Northeast } & -0.166 & 0.232 \\
\hline & -0.002 & -0.002 \\
\hline \multirow{2}{*}{ Central-West } & -0.034 & 0.136 \\
\hline & -0.003 & -0.003 \\
\hline \multirow{2}{*}{ South } & 0.09 & -0.025 \\
\hline & -0.002 & -0.002 \\
\hline Number of observations & $3,947,908$ & $3,947,908$ \\
\hline
\end{tabular}

Source: IBGE, data tabulated by the author.

Note: Robust standard errors are in parentheses. 
According to the theory of domestic production, the division of labor is efficient when each member of the family dedicates his or her time to the most productive labor (Becker, 1973). By being more independent, single women also have a greater probability of entering the labor market.

Women with children under 6 years of age are less likely to be in the workforce. Consistent with other studies, maternity is a principal factor leads to a woman's discontinuity in the labor market (Smock, 2000). The presence of young children leads some mothers to leave the labor market to care for their children. Under Brazilian legislation, businesses are required to give maternity leave to women who have children, thus removing these women from the labor market.

With respect to the levels of education among women and consistent with the theory of increasing returns of education, the results of the probit model show that women with higher levels of education are more likely to enter the labor market. 
Table 3 - Bi-Probit of Married $\times$ Single Women

\begin{tabular}{|c|c|c|}
\hline Married $\times$ Single & Probit to be in the labor market & Probit to become single \\
\hline \multirow{2}{*}{ Constant } & -1.117 & -0.28 \\
\hline & -0.006 & -0.008 \\
\hline \multirow{2}{*}{ Indicator for single } & 0.976 & - \\
\hline & -0.017 & \\
\hline \multirow{2}{*}{ Resident in urban center } & - & 0.384 \\
\hline & & -0.004 \\
\hline \multirow{2}{*}{ Age } & - & -0.045 \\
\hline & & -0.0001 \\
\hline \multirow{2}{*}{ Experience } & 0.61 & $\cdot$ \\
\hline & -0.0004 & \\
\hline \multirow{2}{*}{ Experience squared } & -0.002 & - \\
\hline & $-6.16 \mathrm{E}-06$ & \\
\hline \multirow{2}{*}{ Children $<6$ years } & -0.242 & - \\
\hline & -0.002 & \\
\hline \multirow{2}{*}{1 to 4 years of schooling } & 0.222 & -0.191 \\
\hline & -0.003 & -0.005 \\
\hline \multirow{2}{*}{5 to 8 years of schooling } & 0.42 & -0.147 \\
\hline & -0.003 & -0.006 \\
\hline \multirow{2}{*}{9 to 11 years of schooling } & 0.753 & -0.101 \\
\hline & -0.003 & -0.006 \\
\hline \multirow{2}{*}{12 to 15 years of schooling } & 1.213 & -0.178 \\
\hline & -0.004 & -0.007 \\
\hline \multirow{2}{*}{ Over 15 years of schooling } & 1.46 & -0.224 \\
\hline & -0.007 & -0.012 \\
\hline \multirow{2}{*}{ Black } & 0.165 & 0.524 \\
\hline & -0.004 & -0.005 \\
\hline \multirow{2}{*}{ Asian } & -0.113 & -0.024 \\
\hline & -0.011 & -0.023 \\
\hline \multirow{2}{*}{ Parda } & 0.043 & 0.215 \\
\hline & -0.002 & -0.003 \\
\hline \multirow{2}{*}{ Indigenous } & 0.051 & 0.198 \\
\hline & -0.014 & -0.023 \\
\hline \multirow{2}{*}{ North } & -0.132 & 0.243 \\
\hline & -0.004 & -0.005 \\
\hline \multirow{2}{*}{ Northeast } & -0.113 & 0,123 \\
\hline & -0.002 & -0.003 \\
\hline \multirow{2}{*}{ Central-West } & 0.002 & 0.02 \\
\hline & -0.003 & -0.02 \\
\hline \multirow{2}{*}{ South } & 0.096 & -0.094 \\
\hline & -0.002 & -0.004 \\
\hline Number of observations & $2,953,074$ & $2,953,074$ \\
\hline
\end{tabular}

Source: IBGE, data tabulated by the author.

Note: Robust standard errors are in parentheses. 
In the two sub-samples, the greater the number of years of schooling, the greater the likelihood of women participating in the labor market. On the other hand, when we examine the likelihood of women engaging in a consensual union, the greater the educational level of the woman, the less likely she is to choose an informal union, indicating that cohabitation is still largely practiced by women with lower educational levels. Thus, a higher level of education increases the probability of entering the labor market and decreases the likelihood of cohabitation. Considering the experience of the women in the sample, more experienced women are more likely to be in the labor market. Experience sends a positive signal to employers and increases the chances of employment and market integration. The fact that these women have many years of experience suggests greater stability to market agents and, consequently, a reduced likelihood of a work interruption.

In agreement with earlier studies, cohabitation seems to be more frequent among younger groups. An increase in age leads to a decrease in the probability of entering an informal union. This fact leads us to observe that older women find greater stability by choosing formal unions; however, in Brazil, as in other Latin American countries, informal unions exist among older women as well. Some studies indicate that non-white women have a greater participation in the labor market, which would lessen the likelihood of discontinuity. In the sub-sample that compares cohabitant and married women, only black women have a greater probability of being in the labor market when compared with white women. Among non-white women, only Asian women have a lower probability of being in informal unions. In other words, black, parda, and indigenous women have a greater probability of cohabitating. In the sub-sample comparing single and married women, only Asian women have a lower probability of being active in the labor market and being in an informal union (cohabitation).

Consistent with the results of Berquó (1998), the informal union is a phenomenon of large urban centers. Being a woman residing in an urban center increases the probability of being in an informal union. The sub-sample that analyzes single women shows that a woman residing in an urban center increases her probability of remaining single. In these two cases, residing in an urban center can be a characteristic that indicates a certain level of independence to 
the market. Considering the two problems of selection and method, we obtained two coefficients using the IMR: one for the correction in the labor market and the other for the correction of choice in marital status. The following sections present the results that were obtained from multiple linear regressions for the two sub-samples: married/cohabitant women (full time and part time) and married/ single women (full time and part time).

\subsection{Married versus Cohabitant Women}

In estimating the results to refine the analysis, we separated the two sub-samples into two groups, women who work full time (at least 40 hours per week) and women who work part time (less than 40 hours per week). ${ }^{17}$ This division allows us to investigate the behavior profiles of these women and the signals that are passed by women to the market according to their dedication (in terms of time) to work.

In the data that are estimated in Table 4, for women who work full time and women who work part time, the probability ratio for entering the workforce positively affects the salaries of women, whether married or cohabitant. This finding indicates the extent to which unobservable characteristics positively influence women's participation in the labor market; as a woman participates, her salary should increase. Women with salary-increasing characteristics are more prone to entering the labor market. A higher probability of choosing marriage positively affects the salaries of married women (equally for full-time and part-time workers) but negatively affects the salaries of cohabiting women. In other words, women who opt for a consensual union suffer reduced salaries.

As anticipated, the number of children decreased salaries for married and cohabiting women who worked full and part time. Maternity is one of the principal factors leading to women's discontinuity in the labor market. The presence of children leads some mothers to leave the labor market to care for these children (Sedlacek and Santos, 1991). Brazilian law requires businesses to give maternal leave to women with children, thus removing these women from the labor market.

\footnotetext{
${ }^{17}$ In the biprobit models for the correction of selection bias, we used a dummy variable for full and part time; however, the influence of the variable was not significant. Thus, we decided to remove the variable from the model.
} 
Table 4 - Multiple Linear Regression Sub-Sample: Married $\times$ Cohabitant

\begin{tabular}{|c|c|c|c|c|}
\hline & \multicolumn{2}{|c|}{ Married } & \multicolumn{2}{|c|}{ Cohabitant } \\
\hline \multirow{3}{*}{ Constant } & Full time & Part time & Full time & Part time \\
\hline & -1.442 & -0.789 & -0.606 & -0.296 \\
\hline & -0.021 & -0.026 & -0.031 & -0.053 \\
\hline \multirow{2}{*}{ IMR - probability of being in the workforce } & 1.359 & 1.073 & 0.809 & 0.826 \\
\hline & -0.026 & -0.033 & -0.051 & -0.085 \\
\hline \multirow{2}{*}{ IMR - probability of being cohabitant } & 0.134 & 0.102 & -0.485 & -0.529 \\
\hline & -0.02 & -0.024 & -0.026 & -0.042 \\
\hline \multirow{2}{*}{ Experience } & 0.059 & 0.044 & 0.048 & 0.041 \\
\hline & -0.001 & -0.001 & -0.001 & -0.002 \\
\hline \multirow{2}{*}{ Experience squared } & -0.001 & -0.001 & -0.001 & -0.001 \\
\hline & -0.00001 & -0.00001 & -0.00002 & -0.00003 \\
\hline \multirow{2}{*}{ Children } & -0.045 & -0.035 & -0.041 & -0.032 \\
\hline & $-0,001$ & -0.001 & -0.001 & -0.001 \\
\hline \multirow{2}{*}{1 to 4 years of schooling } & 0.355 & 0.351 & 0.276 & 0.304 \\
\hline & -0.005 & -0.008 & -0.006 & -0.01 \\
\hline \multirow{2}{*}{5 to 8 years of schooling } & 0.631 & 0.646 & 0.476 & 0.551 \\
\hline & -0.006 & -0.009 & -0.008 & -0.013 \\
\hline \multirow{2}{*}{9 to 11 years of schooling } & 1.21 & 1.191 & 0.887 & 0.946 \\
\hline & -0.008 & -0.011 & -0.012 & -0.019 \\
\hline \multirow{2}{*}{12 to 15 years of schooling } & 2.1 & 1.959 & 1.643 & 1.593 \\
\hline & -0.01 & -0.013 & -0.017 & -0.028 \\
\hline \multirow{2}{*}{ Over 15 years of schooling } & 2.603 & 2.441 & 2.083 & 2.058 \\
\hline & -0.011 & -0.014 & -0.022 & -0.035 \\
\hline \multirow{2}{*}{ Black } & -0.282 & -0.214 & -0.225 & -0.186 \\
\hline & -0.004 & -0.006 & -0.005 & -0.009 \\
\hline \multirow{2}{*}{ Parda } & -0.221 & -0.17 & -0.165 & -0.153 \\
\hline & -0.003 & -0.003 & -0.003 & -0.005 \\
\hline \multirow{2}{*}{ Asian } & 0.303 & 0.266 & 0.156 & 0.212 \\
\hline & -0.015 & -0.021 & -0.03 & -0.052 \\
\hline \multirow{2}{*}{ Indigenous } & -0.322 & -0.208 & -0.226 & -0.176 \\
\hline & -0.018 & -0.024 & -0.02 & -0.032 \\
\hline \multirow{2}{*}{ North } & -0.175 & -0.171 & -0.273 & 0.197 \\
\hline & -0.005 & -0.007 & -0.006 & -0.009 \\
\hline \multirow{2}{*}{ Northeast } & -0.45 & -0.452 & -0.523 & 0.486 \\
\hline & -0.003 & -0.003 & -0.004 & -0.006 \\
\hline \multirow{2}{*}{ Central-West } & -0.075 & -0.149 & -0.153 & -0.178 \\
\hline & -0.004 & -0.005 & -0.004 & -0.007 \\
\hline \multirow{2}{*}{ South } & -0.107 & -0.14 & -0.102 & -0.16 \\
\hline & -0.002 & -0.003 & -0.004 & -0.006 \\
\hline \multirow{2}{*}{ Head of household } & 0.021 & 0.05 & 0.005 & 0.034 \\
\hline & -0.002 & -0.003 & -0.002 & -0.004 \\
\hline Indicator of occupation & Yes & Yes & Yes & Yes \\
\hline R2 & 0.4848 & 0.4489 & 0.4641 & 0.3705 \\
\hline Number of observations & 636,087 & 382,801 & 296,213 & 142,963 \\
\hline
\end{tabular}

Source: IBGE, data tabulated by the author.

Note: Robust standard errors are in parentheses. 
According to the socioeconomic characteristics of these women and the theory of increasing returns of education, the higher a woman's education level, the higher the salary level for both married and cohabiting women is, whether working full time or part time. With regards to race, cohabitating and married Asian women working either full or part time have a higher wage premium than white women. Considering the geographical region in which women live, the results did not differ for married and cohabiting women who work full or part time. Women living in the southeast have higher incomes than women living in other regions. Finally, when a woman is the head of a household, her salary is greater in all cases than those of women who are not the heads of the household.

\subsection{Married versus Single Women}

As shown in Table 5, similar to the married-cohabitant sub-sample and regardless of full-time or part-time status, a greater probability of entering the workforce positively affects women's earnings, whether married or unmarried, indicating that as women have more unobservable characteristics that positively influence their participation in the labor market, their salaries should increase. A greater probability of choosing marriage negatively affects the salaries of married and single women (equally for full-time and part-time workers); however, the impact seems to be greater on the salaries of single women, indicating that more women who remain single have lower salaries than married women. As maternity is a principal factor leading to women's discontinuity in the labor market for all women in the sub-sample, the presence of children negatively affects wages. According to the socioeconomic characteristics of these women and based on the theory of increasing returns of education, a higher level of education will generally result in a woman earning a higher salary; this trend holds both married and single women, regardless of full- or part-time work. With respect to race, among single and married women, only Asian women, working both full and part time, have a higher wage premium than white women. When considering geographic region, the results are similar for married and single women who work full- or part-time; however, women who live in the southeast region have higher salaries than those living in other regions. Finally, if a woman is the head of the household, her salary as a married woman increases. However, for single women 
who work full time, being the head of the family results in lower salaries, which could be related to the fact that these women work in occupations that do not require skilled labor and, therefore, receive lower wages.

Table 5 - Multiple Linear Regression Sub-Sample: Married $\times$ Single

\begin{tabular}{|c|c|c|c|c|}
\hline & \multicolumn{2}{|c|}{ Married } & \multicolumn{2}{|c|}{ Single } \\
\hline \multirow{3}{*}{ Constant } & Full time & Part time & Full time & Part time \\
\hline & -0.722 & -0.229 & -0.418 & -0.163 \\
\hline & -0.025 & -0.035 & -0.057 & -0.112 \\
\hline \multirow{2}{*}{ IMR - probability of being in the workforce } & 0.547 & 0.406 & 0.881 & 0.951 \\
\hline & -0.025 & -0.036 & -0.108 & -0.218 \\
\hline \multirow{2}{*}{ IMR - probability of being single } & -0.183 & -0.126 & -0.439 & -0.351 \\
\hline & -0.007 & -0.01 & -0.035 & -0.061 \\
\hline \multirow{2}{*}{ Experience } & 0.045 & 0.033 & 0.036 & 0.031 \\
\hline & -0.001 & -0.001 & -0.002 & -0.005 \\
\hline \multirow{2}{*}{ Experience squared } & -0.001 & -0.001 & -0.001 & -0.001 \\
\hline & -0.00002 & -0.00003 & -0.00006 & -0.0001 \\
\hline \multirow{2}{*}{ Children } & -0.046 & -0.036 & -0.042 & -0.026 \\
\hline & -0.0006 & -0.0008 & -0.003 & -0.005 \\
\hline \multirow{2}{*}{1 to 4 years of schooling } & 0.308 & 0.31 & 0.205 & 0.221 \\
\hline & -0.005 & -0.007 & -0.015 & -0.034 \\
\hline \multirow{2}{*}{5 to 8 years of schooling } & 0.541 & 0.574 & 0.33 & 0.404 \\
\hline & -0.006 & -0.009 & -0.018 & -0.039 \\
\hline \multirow{2}{*}{9 to 11 years of schooling } & 0.989 & 1.017 & 0.563 & 0.696 \\
\hline & -0.008 & -0.011 & -0.024 & -0.049 \\
\hline \multirow{2}{*}{12 to 15 years of schooling } & 1.79 & 1.719 & 1.243 & 1.313 \\
\hline & -0.011 & -0.016 & -0.033 & -0.064 \\
\hline \multirow{2}{*}{ Over 15 years of schooling } & 2.258 & 2.172 & 1.654 & 1.713 \\
\hline & -0.013 & -0.019 & -0.044 & -0.077 \\
\hline \multirow{2}{*}{ Black } & -0.271 & -0.197 & -0.206 & -0.145 \\
\hline & -0.004 & -0.006 & -0.01 & -0.02 \\
\hline \multirow{2}{*}{ Parda } & -0.198 & -0.149 & -0.153 & -0.123 \\
\hline & -0.002 & -0.003 & -0.006 & -0.012 \\
\hline \multirow{2}{*}{ Asian } & 0.299 & 0.262 & 0.107 & 0.266 \\
\hline & -0.015 & -0.021 & -0.054 & -0.106 \\
\hline \multirow{2}{*}{ Indigenous } & -0.157 & -0.072 & -0.126 & -0.033 \\
\hline & -0.018 & -0.024 & -0.051 & -0.112 \\
\hline \multirow{2}{*}{ North } & -0.137 & -0.143 & -0.26 & -0.215 \\
\hline & -0.005 & -0.007 & -0.011 & -0.02 \\
\hline \multirow{2}{*}{ Northeast } & -0.43 & -0.437 & -0.472 & 0.465 \\
\hline & -0.003 & -0.004 & -0.007 & -0.014 \\
\hline \multirow{2}{*}{ Central-west } & -0.068 & -0.144 & -0.1 & -0.094 \\
\hline & -0.004 & -0.005 & -0.009 & -0.017 \\
\hline \multirow{2}{*}{ South } & -0.115 & -0.146 & -0.102 & -0.162 \\
\hline & -0.002 & -0.004 & -0.008 & -0.016 \\
\hline \multirow{2}{*}{ Head of household } & 0.02 & 0.05 & -0.016 & 0.001 \\
\hline & -0.002 & -0.003 & -0.005 & -0.01 \\
\hline Indicator of occupation & Yes & Yes & Yes & Yes \\
\hline $\mathrm{R} 2$ & 0.4844 & 0.4483 & 0.4704 & 0.3791 \\
\hline Number of observations & 636,087 & 382,801 & 63,575 & 22,650 \\
\hline
\end{tabular}

Source: IBGE, data tabulated by the author.

Note: Robust standard errors are in parentheses. 


\subsection{The Results of Salary Differences}

By assessing the impact of variables on wages presented in Table 6 , we find that in the married-cohabitants sub-sample, the salaries of women in consensual unions and those in formal unions are very different. That is, cohabiting women who work full time earn 3.67 per cent more than married women do on average; however, this difference is not explained by observable characteristics among women. This finding provides strong evidence of problems with information asymmetry. In other words, the unobservable characteristics of married women represent a large part of the labor differences. When we analyze women who work part time, the result changes such that cohabitant women earn, on average, 1.32 per cent less than married women. This fact seems to be related to the information that women in consensual unions provide to the market.

As much as being engaged in a union (formal or informal) signals better life conditions (see Waite and Gallagher, 2000), especially for women, this union may represent less freedom to travel, move abroad, etc. Our results indicate that employees consider the positive effects of women belonging to a couple to be greater for those that work full time and less for those that work part time. A full-time worker who is also a cohabitant signals a positive selection compared with the female population integrally dedicated to the labor market. However, a part-time female worker who is a cohabitant sends negative signals by not being in a formal union and indicates less dedication to the labor market. Considering these two findings together reveals lower wages when compared with part-time female workers who are married.

Table 6 - Oaxaca-Kuhn Test of Wage Differences ${ }^{18}$

\begin{tabular}{lcc}
\hline Oaxaca test & Married $\times$ Cohabitant & Married $\times$ Single \\
\hline Full-time work & 0.0367 & -0.1512 \\
Part-time work & -0.0132 & -0.1191 \\
\hline
\end{tabular}

Source: IBGE, data tabulated by the author.

18 Tests were performed to find the average differences for the population so as to examine the statistical validity of the differential. For all sub-samples, the wage differences are statistically significant. 
Analyzing Table 7, among the observable variables, the occupational activities that women perform and their educational levels have the greatest influence on the wage differences among women. ${ }^{19}$ For women who work full time, nearly 38 per cent of the total difference between the salaries of cohabitant and married women is due to educational level. When we analyze women who work part time, nearly 26 per cent of the difference between the salaries of cohabitant and married women is due to educational level, whereas nearly 36 per cent is due to occupational activities.

Table 7 - Variables that Have the Greatest Impact on Wage Differences among Married, Single, and Cohabiting Women

\begin{tabular}{lcccc}
\hline Impact on differential & \multicolumn{2}{c}{ Married $\times$ Cohabitant } & \multicolumn{2}{c}{ Married $\times$ Single } \\
\hline & Full time & Part time & Full time & Part time \\
Education Level & $37.81 \%$ & $26.16 \%$ & $76.93 \%$ & $63.02 \%$ \\
Occupational Activity & $13.09 \%$ & $35.80 \%$ & $10.41 \%$ & $23.33 \%$ \\
\hline
\end{tabular}

Source: IBGE, data tabulated by the author.

An analysis of the occupational activities of women working part time shows that agriculture, domestic services, and manufacturing industries provide lower wages for both married women and women in informal unions. Among cohabiting women, the lowest salaries are paid to those who work in the agricultural sector, whereas among married women, domestic services and manufacturing occupations are among those most poorly paid. Consular and international activities and the financial and production sectors are those that offer the greatest pay for the two classes of women, respectively.

From the married-single sub-sample, it is evident that the salaries of single and married women are very different in that single women who work full time earn, on average, 15.12 per cent less than married women. When we analyze women who work part time, the result is similar, i.e., single women continue to earn, on average, 11.91 per cent less than married women. This fact could be related to characteristics that are linked to age, maturity, and stability that these women transmit to agents in the market.

${ }^{19}$ Adjustments were made to test the interpretations of Oaxaca for dummies according to Scorzafave and Pazello (2007). 
Just as for the sub-sample of married-cohabitant women depicted in Table 7, observable variables with the greatest influence on the wage differences of these women are that their occupations and educational levels. ${ }^{20}$ In the case of women who work full time, nearly 77 per cent of the total difference between the salaries of single and married women is due to their educational levels. Nearly 10 per cent of the total difference between the salaries of these women is due to occupational activity. When we analyze women who work part time, nearly 63 per cent of the total difference between salaries of single and married women is due to educational levels, whereas nearly 23 per cent of the total difference between the salaries of these women is due to their occupation.

Women who hold part-time positions or work in the agriculture, domestic services, and manufacturing industries have the lowest wages for both married and single women. For single and married women, the lowest wages are paid to those working in manufacturing. The consular and international sectors and the financial and production sectors are pay better for the two classes of women, respectively.

\section{Final Considerations}

The primary objective of this study was to investigate the wage differences of women according to their marital status. The motivation was the marriage premium that is estimated for male wages and the previous marriage penalty estimated for women residing in other countries (as Madalozzo, 2008, and Kiernan, 2002). In addition, cohabitation has been becoming more popular in Brazil in recent years, primarily in urban centers, which encouraged the study of the effects of this new marital choice with respect to female wages. Using 2000 census data and controlling for the two selection problems and using econometric techniques that have been specified in Lee (1983) and Oaxaca (1973), we used OLS to investigate the wage differences for women from two sub-samples: married-cohabitant and married-single women.

${ }^{20}$ As cited above, adjustments were made to test the interpretations of Oaxaca for dummies according to Scorzafave and Pazello (2007). 
The empirical results from multiple linear regressions show that women in informal unions who work in full-time jobs have greater earnings than those in formal unions. These results indicate an information asymmetry problem. That is, by some measure, being in an informal union means - to employees - that a woman is more productive than if she were married (because the woman in an informal union signals her ability to have a partner and still have freedom to move, travel, stay longer hours at work, etc.), and accordingly, married women earn lower wages than cohabitants when working full time. For women who work part time, the situation is inverted: cohabiting women earn a lower salary compared with married women. Our interpretation of this latter result is that, although this cohabiting woman has a better life condition by living with a partner (Waite and Gallagher, 2000), her union is less stable than a formal marriage and she signals less attachment to the labor market by being a part-time worker. When we analyze single women, whether they work full time or part time, single women have lower wages than married women. These results reflect the problem of perceptions of characteristics that are related to maturity, experience, and the establishment of women by agents of the market.

On the basis of the method used by Scorzafave and Pazello (2007), among the observable variables analyzed for the two sub-samples, women's occupations and educational levels have the greatest impacts on wage differences. For women working full time in the two sub-samples, educational level has a greater impact on wage differences. For women who work part time, occupational activity has the strongest effect on wage differences.

This study's contribution is demonstrating that the problems of selection in the workforce and choosing marital status should be considered when assessing the status of women in the workforce; otherwise, there will be bias problems in the final results. After controlling for the two selection problems, we arrive at a consistent estimate of the wage differences and the conclusion that there is a penalty for cohabiting. The results illustrate that, according to the working position, the impact of the conjugal status may vary. 


\section{References}

ALLEGRETTO, S.; ARTHUR, M. "An Empirical Analysis of Homosexual/Heterosexual Male Earnings Differences: Unmarried and Unequal?” Industrial and Labor Relations Review, 54:3, p. 631-646. 1999.

BECKER, G. "A Theory of the Allocation of Time”, Economic Journal, 75, p. 493-508. 1965.

BECKER, G. “A Theory of Marriage I”, Journal of Political Economy, 81: 4, p. 813-846. 1973.

BECKER, G. “A Treatise on the Family”, Cambridge, London: Harvard University Press, 1992.

BECKER, G. "Human Capital, Effort, and the Sexual Division of Labor", Journal of Labor Economics, 3(1): p. 33-59. 1985.

BERQUÓ, E. "Family Arrangements in Brazil: A Demographic View”, in SCHWARCZ, L. M. (Ed.) History of Private Life in Brazil: Contrasts of Contemporary Intimacy. São Paulo: Companhia Das Letras, p. 411-437. 1998.

BRIEN, M.; LILLARD, L.; WAITE, L. "Irrelated Family-Building Behaviors: Cohabitation, Marriage and Nonmarital Conception”. Demography, 36: 4, p. 531-551, 1999.

BUMPASS, L.; SWEET, J.; CHERLIN, A. “The Role of Cohabitation in Declining Of Marriage', Journal of Marriage and the Family, 53, p. 913-917, 1991.

CHEVAN, A. "As Cheaply as One: Cohabitation in the Older Population", Journal of Marriage and Family, 58(3), p. 656-667. 1996.

CHIAPPORI, P. "Rational household labor supply”, Econometrica, 56(1), p. 63-90. 1988.

FALCÃO, B.; SOARES, R. 'The Demographic Transition and the Sexual Division Labor', Journal Of Political Economy, 116: 6, p.1058-1104. 2008.

FERBER, Marianne A.; BIRNBAUM, Bonnie G. "The "New Home Economics": Retrospects and Prospects”, The Journal of Consumer Research, Vol. 4, Issue 1, p. 19-28. 1977.

GREENE, M.; RAO, V. 'Compression of the Marriage Market and the Increase of Consensual Unions in Brazil’, Brazilian Journal of Population Studies, 9: 2, p. 168-83. 1992.

HANSON, S.; PRATT, G. 'Job Search and the Occupational Segregation of Women', Annals of the Association of American Geographers, 31: 2, p. 229-53. 1991.

HECKMAN, J. 'Sample Selection Bias as a Specification Error', Econometrica, 47: 1, p.153-62. 1979.

HERSCH, J.; STRATTON, L. S. 'Household specialization and the male marriage wage premium' Industrial \& Labor Relations Review, 54(1): 78-94. 2000.

HILL, M. 'The Wage Effects of Marital Status and Children', The Journal of Human Resources, 14: 4, p. 579-94. 1979.

HOFFMAN, R.; KASSOUF, A. 'Deriving conditional and unconditional marginal effects in log earnings equations estimated by Heckman's Procedure”, Applied Economics, 37:11, p. 1303-1311. 2005.

KIERNAN, K. 'Cohabitation in Western Europe: Trends, Issues, and Implications', in A. Booth and Ann C. Crouter (eds.), Just Living Together: Implications of Cohabitation on Families, Children and Social Policy (Lawrence Erlbaum Associates, Inc.). 2002.

KOREMAN, S.; NEUMARK, D. 'Does Marriage Really Make Men More Productive?' The Journal of Human Resources, 24: 2, p. 282-307. 1991.

KUHN, P. 'Sex Discrimination in Labor Markets: The Role of Statistical Evidence', The American Economic Review, 77: 4, p.567-583. 1987.

LEE, L. 'Generalized Econometric Models with Selectivity', Econometrica, 51: 2, p. 507-12. 1983.

LUNDBERG, S.; POLLAK, R. "Separate Spheres Bargaining and the Marriage Market”, Journal of Political Economy, 110(6): 988-1010. 1993. 
MADALOZZO, R. ‘An Analysis of Income Differences by Marital Status', Estudos Econômicos, 38: 2, p.267-292. 2008.

MANSER, M.; BROWN, M. "Marriage and Household Decision-making: a Bargain Analysis", International Economic Review, 21(XX): 31-44. 1980.

MARTIN, T. C. 'Consensual Unions in Latin America: Persistence of a Dual Nuptiality System', Journal of Comparative Family Studies, 33: 1, p.35-55. 2002.

MILLER, P. 'The Gender Pay Gap in The US: Does Sector Make a Difference?', Journal of Labor Research, 30: 1, p. 51-74. 2009.

MIRANDA-RIBEIRO, P. 'Starting Again: A Comparative Study of Mismatch Remarriage', unpubl. MA thesis, Center of Regional Development and Planning, Federal University of Minas Gerais, Belo Horizonte. 1993.

MOORE, W.; WILSON, R. 'The Influence of Children on the Wage Rates of Married Women', Eastern Economic Journal, 3: 3, p. 197-210. 1982.

OAXACA, R. 'Male-Female Wage Differences in Urban Labor Markets', International Economic Review, 14: 3, p. 693-709. 1973.

SAHA, A.; CAPPS JR, O.; BYRNE, P. 'Calculating marginal effects in models for zero expenditures in household budgets using a Heckman-type Correction', Applied Economics,29:10, p. 13111316. 1997.

SCORZAFAVE, L.; PAZELLO, E. "Using Normalized Equations to Solve the Indetermination Problem in the Oaxaca-Blinder Decompositions: An Application to the Gender Wage Gap in Brazil', Economia Aplicada, 61: 4, p. 535-548. 2007.

SEDLACEK, G.; SANTOS, E. 'The Female Spouse in the Labour Market as a Strategy for Generating Income', Economic Research and Planning, 21: 3, p. 449-70. 1991.

SMOCK, P. J. 'Cohabitation in the United States: An Appraisal of Research Themes, Findings, and Implications', Annual Review of Sociology, 26, pp. 1-20. 2000.

VELLA, F. 'Estimating models with sample selection bias: a survey', The Journal of Human Resources, 33:1, pp. 127-169. 1998.

WAITE, L.; GALLAGHER, M. 'The Case for Marriage: Whay Married People are Happier, Healthier, and Better off Financially”, New York: Broadway Books. 2000.

ZAVODNY, M. 'Is There a 'Marriage Premium' for Gay Men?' Review of Economics of the Household, 6(4): 369-89. 2008. 